\title{
Pemilihan Supplier Menggunakan Metode Relaxed-Normalized Goal Programming untuk Mengoptimalkan Proses Pengadaan Produk (Studi Kasus: Giant Ekstra Diponegoro Surabaya)
}

\author{
Fadly Syahputra, Wiwik Anggraeni \\ Jurusan Sistem Informasi, Fakultas Teknologi Informasi, Institut Teknologi Sepuluh Nopember (ITS) \\ J1. Arief Rahman Hakim, Surabaya 60111 Indonesia \\ e-mail: wiwik@its-sby.edu
}

\begin{abstract}
Abstrak - Supplier merupakan salah satu mitra bisnis yang memegang peranan sangat penting dalam menjamin ketersediaan barang pasokan yang dibutuhkan oleh perusahaan. Sebuah perusahaan yang sehat dan efisien tidak akan banyak berarti apabila supplier-supplier-nya tidak mampu menghasilkan bahan baku yang berkualitas atau tidak mampu memenuhi pengiriman tepat waktu. Oleh karena itu, perusahaan perlu menilai supplier secara cermat. Banyak kriteria yang dapat dipertimbangkan di dalam memilih supplier.

Untuk menyelesaikan permasalahan dalam menentukan supplier terbaik, peneliti mencoba mengimplementasikan pendekatan relaxed-normalized goal programming (R-NGP), yang dikembangkan dari metode weighted goal programming (WGP), yang akan digunakan untuk menyelesaikan permasalahan dalam melakukan pemilihan supplier dengan tujuan atau kriteria lebih dari satu, sesuai dengan kriteria dan batasan yang ditentukan.

Tugas akhir ini akan menghasilkan daftar dan alokasi order dari tiap supplier terpilih dengan tingkat konsistensi yang baik di antara semua fungsi tujuan sehingga hasil model optimasi ini dapat bermanfaat bagi Giant Ekstra Diponegoro Surabaya di masa mendatang.
\end{abstract}

Kata Kunci- Masalah multikriteria, pemilihan supplier, relaxed-normalized goal programming, weighted goal programming

\section{PENDAHULUAN}

$S$ UPPLIER merupakan salah satu mitra bisnis yang memegang peranan sangat penting dalam menjamin ketersediaan barang pasokan yang dibutuhkan oleh perusahaan. Sebuah perusahaan yang sehat dan efisien tidak akan banyak berarti apabila supplier-supplier-nya tidak mampu menghasilkan bahan baku yang berkualitas atau tidak mampu memenuhi pengiriman tepat waktu. Oleh karena itu, perusahaan perlu menilai supplier secara cermat [1].

Penilaian supplier membutuhkan berbagai kriteria guna menggambarkan performa dari supplier secara keseluruhan sehingga dapat membantu para decision maker dalam menentukan pilihan. G.W. Dickson (1966) melakukan penelitian untuk mengidentifikasi kriteria-kriteria yang digunakan dalam memilih supplier dengan mengirimkan kuesioner ke 273 agen dan manajer pengadaan di USA dan Kanada. Dickson mengidentifikasi ada 23 kriteria yang harus dipertimbangkan dalam melakukan pemilihan supplier, di antaranya adalah kualitas, pemenuhan pesanan, riwayat performa perusahaan, pemberian garansi, harga, dan lain-lain
[2]. Namun, pada kenyataannya setiap perusahaan mungkin memiliki prioritas kriteria-kriteria yang berbeda di dalam strategi pembelian material dan komponen produksinya [3].

Pemilihan supplier yang tidak tepat akan dapat meningkatkan biaya produksi. Penelitian sebelumnya menunjukkan bahwa $70 \%$ dari biaya produksi dihasilkan dari pembelian material dan komponen produksi [4]. Karena alasan tersebut, supplier memainkan peranan sangat penting di dalam sebuah perusahaan. Ketika supplier dapat menyediakan perusahaan dengan harga yang rendah dan kualitas material yang baik pada waktu yang tepat, perusahaan juga dapat melakukan hal yang sama kepada pelanggannya [5].

Banyak metode yang telah dikembangkan peneliti untuk menyelesaikan masalah pemilihan supplier terutama dengan banyak tujuan. Metode-metode tersebut telah berhasil diimpelementasikan di banyak sektor permasalahan [6]. Kumar et al. (2004) menerapkan fuzzy mixed integer goal programming [7] dan Amid et al. (2011) menerapkan fuzzy multi-objective [8] untuk menentukan supplier dengan tujuan biaya, kualitas, dan delivery. Ustun dan Demirtas (2008) menggabungkan metode min-max goal programming (MGP) dan weighted goal programming (WGP) untuk menyelesaikan masalah multi tujuan [9]. Nazari-Shirkouhi et al. (2013) mengembangkan fuzzy goal programming untuk menentukan supplier dengan fungsi tujuan lebih dari satu (fuzzy multiobjective) [10]. Dan masih banyak lagi penelitian terkait penyelesaian masalah penentuan supplier dengan fungsi tujuan lebih dari satu.

Studi kasus di dalam penelitian ini adalah Giant Ekstra Diponegoro Surabaya. Giant adalah salah satu perusahaan retail terbesar di Indonesia. Giant menjual produk yang begitu banyak dan beragam. Produk yang dijual di Giant Hypermarket mayoritas dipasok oleh supplier/vendor karena Divisi Merchandising (MD) Regional Surabaya bertanggung jawab dalam menentukan harga beli dan jual, supplier, kuantitas, dan sebagainya yang berhubungan dengan produk yang berada di kategori fresh. Di dalam menentukan supplier, MD Regional Surabaya hanya mempertimbangkan faktor harga, kualitas, dan kuantitas.

Permasalahan disini adalah ketika ketiga faktor di atas terpenuhi, namun di saat proses pengiriman terjadi beberapa masalah, seperti keterlambatan atau ada beberapa produk yang tidak sesuai dengan standar Giant.

Untuk mengoptimalkan pemilihan supplier, peneliti 
mencoba memasukkan faktor ekspektasi dari jumlah produk yang mungkin akan ditolak karena cacat dan ekspektasi dari jumlah produk yang mungkin akan datang terlambat di tiap supplier sehingga dapat memperkecil kemungkinan Giant mengalami kegagalan dalam meraup keuntungan yang lebih besar. Peneliti akan mengimplementasikan pendekatan normalized goal programming. Metode yang dikembangkan oleh O. Jadidi et.al. (2014) ini adalah pengembangan dari weighted goal programming (WGP) yang akan digunakan untuk menyelesaikan permasalahan dalam melakukan pemilihan supplier dengan tujuan atau kriteria lebih dari satu, sesuai dengan kriteria dan batasan yang ditentukan [11].

\section{KAJIAN PUSTAKA}

\section{A. Supply Chain Management}

Supply chain adalah seperangkat pendekatan untuk mengefisiensikan integrasi supplier, manufaktur, gudang, dan penyimpanan, sehingga barang diproduksi dan didistribusikan dalam jumlah yang tepat, lokasi yang tepat, waktu yang tepat, untuk meminimasi biaya dan memberikan kepuasan layanan terhadap konsumen [12]. Tujuan yang ingin dicapai dari sebuah proses supply chain adalah untuk memaksimalkan nilai yang dihasilkan secara keseluruhan [13]. Supply chain yang terintegrasi dengan baik akan meningkatkan value yang dihasilkan oleh supply chain tersebut.

\section{B. Pemilihan Supplier}

Secara umum, ada dua tipe dalam memilih supplier. Yang pertama, satu supplier dapat memenuhi semua kebutuhan perusahaan (single sourcing). Manajemen hanya perlu membuat satu keputusan; supplier mana yang terbaik. Tipe kedua, dibutuhkan banyak supplier untuk memenuhi semua kebutuhan perusahaan (multiple sourcing) karena tidak ada supplier yang dapat menyanggupi seluruh kebutuhan perusahaan. Di antara kedua tipe pemilihan supplier tersebut, banyak tantangan yang harus dihadapi Decision Maker (DM) dan banyak kriteria yang harus dipertimbangkan dalam memilih supplier yang paling tepat untuk perusahaan guna meningkatkan daya saing di pasaran [14].

Para DM harus berpikir objektif di dalam memilih supplier. Namun pada kenyataannya, pengambilan keputusan biasanya hanya bersifat intuitif atau subjektif [15] serta berdasarkan pengalaman saja. Tidak adanya prosedur atau metode pemilihan yang jelas atau pemilihan supplier hanya berdasarkan kriteria-kriteria umum saja, seperti harga yang murah, biaya transportasi terjangkau, kuantitas tercukupi, dan sejenisnya. Padahal banyak kriteria lainnya yang dapat dipertimbangkan para DM untuk menentukan supplier terbaik, di antaranya adalah riwayat performa perusahaan, kebijakan garansi, fasilitas produksi, dan lain-lain.

\section{Normalized Goal Programming}

Normalized Goal Programming (NGP) adalah pengembangan dari metode Weighted Goal Programming. Dengan metode NGP, diharapkan hasil yang didapatkan dapat konsisten dengan yang diharapkan oleh decision maker (DM).
Teknik ini mencoba untuk mengabaikan unit yang berbeda dari variabel deviasi yang diharapkan dengan menghilangkan bias terhadap tujuan utama yang ingin dicapai (opposite deviation).

Sudah banyak peneliti yang menyadari bahwa Goal Programming harus dinormalisasi ketika akan digunakan untuk menjamin konsistensinya. Menurut mereka, hasil yang didapatkan dari GP harus sebisa mungkin konsisten dengan aspirasi dari para DM.

O. Jadidi, et al. (2014) meneliti pemilihan supplier dengan tujuan meminimalisasi harga, defect rate, dan keterlambatan produk dengan metode Relaxed-NGP (R-NGP). Mereka menormalisasi deviasi dari ketiga fungsi tujuan tersebut menggunakan,

$$
\frac{\left[\left(f_{k}^{*}-f_{k}^{+}\right) y_{2}+\left(f_{k}^{-}-f_{k}^{*}\right) y_{1}+\left(d_{k}^{-}-d_{k}^{+}\right)\right]}{\left[\left(f_{k}^{*}-f_{k}^{+}\right) y_{2}+\left(f_{k}^{-}-f_{k}^{*}\right) y_{1}\right]}=\lambda
$$

dimana :

$y_{1}=0$ dan $y_{2}=1$ jika $\lambda>1$

$y_{1}=1$ dan $y_{2}=0$ jika $\lambda<1$

salah satu $y_{1}$ atau $y_{2}=1$ jika $\lambda=1$

$k=1,2,3(\lambda \in[0,2])$

Sebagai tambahan, $f_{k}^{+}=\frac{\left.\operatorname{minf}_{k}(X)\right\}}{X \in S} k$ disebut sebagai positive ideal solution (PIS) atau hasil terbaik dan $f_{k}^{-}=$ $\frac{\max (X)\}}{x \in S} k$ disebut sebagai negative ideal solution (NIS) atau hasil terburuk dari tujuan minimisasi $k^{\text {th }}$, dimana $\mathrm{S}$ adalah feasible set.

Konsep konsistensi yang dimaksud oleh O. Jadidi, et al. (2014) adalah semua hasil yang didapat harus proporsional atau sebanding.
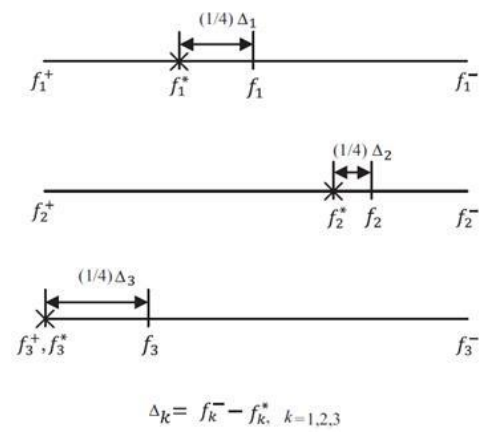

Gambar 1 : Konsep konsitensi

Sebagai contoh, asumsikan $f_{1}^{+}=50, f_{1}^{-}=80, f_{1}^{*}=60, f_{2}^{+}$ $=300, f_{2}^{-}=400, f_{2}^{*}=370, f_{3}^{+}=150, f_{3}^{-}=300, \operatorname{dan} f_{3}^{*}=150$. Kemudian, asumsikan juga hasil akhir yang didapat adalah $f_{1}=$ $65, f_{2}=377,5$, dan $f_{3}=187,5$. Untuk melihat rasio semua fungsi tujuan, digunakanlah $\left(f_{k}-f_{k}^{*}\right) /\left(f_{k}^{-}-f_{k}^{*}\right)$. Hasilnya semua fungsi tujuan menunjukkan rasio yang sama yakni 0,25. Hasil akhir tersebut dapat dikatakan sebanding karena jarak antara hasil akhir yang didapat dengan goal untuk ketiganya adalah sama. Dengan begitu, dapat dikatakan bahwa hasil akhir yang didapat untuk semua fungsi tujuan adalah konsisten. 
Untuk mengevaluasi konsistensi dari solusi yang didapatkan oleh R-NGP, digunakanlah rasio seperti berikut:

$$
R_{k}^{+}=\frac{y_{1}\left(f_{k}-f_{k}^{*}\right)}{f_{k}^{-}-f_{k}^{*}} \quad R_{k}^{-}=\frac{y_{2}\left(f_{k}^{*}-f_{k}\right)}{f_{k}^{*}-f_{k}^{+}}
$$

Nilai konsistensi didapat jika $\lambda<1, R_{1}^{+}=R_{2}^{+}=R_{3}^{+}>0$ dan $R_{k}^{-}=0, k=1,2,3$. Untuk $\lambda>1, R_{1}^{-}=R_{2}^{-}=R_{3}^{-}>0$ dan $R_{k}^{+}=0, k=1,2,3$. Untuk $\lambda=1$, salah satu $R_{k}^{+}$atau $R_{k}^{-}=$ 0 , bergantung dengan nilai $y_{1}$ dan $f_{2}$. Jika rasio konsistensi dari ketiga fungsi tujuan memiliki nilai yang sama, maka hasilnya proporsional.

\section{METODE PENELITIAN}

\section{A. Data Masukan}

Data yang digunakan dalam penelitian antara lain :

a. Data jumlah permintaan produk

b. Data kapasitas tiap supplier

c. Harga per supplier

d. Ekspektasi rasio cacat barang per supplier

e. Ekspektasi rasio keterlambatan pengiriman per supplier

\section{B. Proses Pembuatan Model}

Di dalam membuat model, dibutuhkan data masukan yang didapat dari proses wawancara kepada pihak Giant. Data masukan yang bersifat kuantitatif kemudian akan diformulasikan melalui beberapa tahap ke dalam bentuk Normalized Goal Programming. Setelah diformulasikan, data tersebut akan diproses menggunakan aplikasi Matlab dan QM untuk dicari hasil mana yang paling optimal.

a. Fungsi tujuan

- Meminimalkan biaya pengadaan produk buah

- Meminimalkan produk cacat

$\left(f_{1}\right)$

- Meminimalkan keterlambatan produk datang

b. Variabel keputusan

- Harga buah/kg dari supplier $i$

- Jumlah pesanan buah ke supplier $i$

- Ekspektasi rasio cacat barang dari supplier I

- Ekspektasi keterlambatan produk datang dari supplier $i$

c. Batasan

- Jumlah permintaan dari Giant Ekstra Diponegoro Surabaya

- Kapasitas tiap supplier

Model linear programming dari item-item di atas adalah sebagai berikut.

$$
\begin{aligned}
& \min f_{1}=\sum_{i=1}^{n} C_{i} x_{i} \\
& \min f_{2}=\sum_{i=1}^{n} q_{i} x_{i} \\
& \min f_{3}=\sum_{i=1}^{n} F_{i} x_{i}
\end{aligned}
$$

Dibatasi dengan

$$
\begin{aligned}
& \sum_{i=1}^{n} x_{i}=D \\
& x_{i} \leq V_{i} ; i=1,2, \ldots, n \\
& x_{i} \geq 0 ; i=1,2, \ldots, n
\end{aligned}
$$

dimana $n$ adalah jumlah supplier buah.

Metode normalized goal programming merupakan pengembangan dari metode weighted goal programming (WGP). Metode WGP membutuhkan decision maker untuk menentukan nilai hasil yang diharapkan untuk setiap fungsi tujuan $\left(f_{k}^{*}\right)$ dan kemudian mencoba untuk meminimalkan variabel deviasi dari goal. Berikut adalah model WGP untuk studi kasus penelitian ini.

$$
\min \sum_{k=1}^{3} W_{k}\left(d_{k}^{+}+d_{k}^{-}\right)
$$

Dibatasi dengan

$$
\begin{aligned}
& f_{k}+d_{k}^{-}-d_{k}^{+}=f_{k}^{*} ; k=1,2,3 \\
& d_{k}^{+} d_{k}^{-}=0 ; k=1,2,3 \\
& d_{k}^{+}, d_{k}^{-} \geq 0 ; k=1,2,3
\end{aligned}
$$

(4), (5), dan (6)

Setelah itu, model normalized goal programming dibentuk dengan menjadi seperti berikut.

$$
\max \lambda
$$

Dibatasi dengan

$$
\begin{aligned}
& f_{k}+d_{k}^{-}-d_{k}^{+} \leq f_{k}^{*} ; k=1,2,3 \\
& f_{k}=f_{k}^{*}-\left(\lambda\left(f_{k}^{*}-f_{k}^{+}\right)-\left(f_{k}^{*}-f_{k}^{+}\right)\right) \\
& d_{k}^{+} d_{k}^{-}=0 ; k=1,2,3 \\
& d_{k}^{+}, d_{k}^{-} \geq 0 ; k=1,2,3
\end{aligned}
$$

(4), (5), dan (6)

Model penelitian di atas hanya akan fokus menggunakan case $\lambda>1$ karena merujuk pada pendapat O.Jadidi, et al. (2014) pada penelitiannya.

\section{Metodologi Penyelesaian dengan Matlab}

Penyelesaian model normalized goal programming dapat dilakukan dengan pembuatan program komputer pada Matlab. Berikut langkah-langkah penyelesaian model dengan program komputer.

a. Memasukkan data awal

Data dan variabel harus diinisialisasi terlebih dahulu. Terdapat enam data yang akan dimasukkan ke dalam program Matlab, antara lain jumlah supplier, jumlah permintaan total, target tiap goal yang ingin dicapai, kemungkinan nilai terbaik (PIS) dari tiap goal, nilai lamda $(\lambda)$, dan kapasitas tiap supplier.

b. Membuat variabel keputusan

c. Memasukkan data inisialisasi nilai awal x0, lb, dan ub 
d. Memasukkan batasan fungsi tujuan

e. Memasukkan batasan normalisasi

f. Memasukkan batasan jumlah pesanan

g. Memasukkan batasan variabel deviasi

h. Memasukkan fungsi optimasi

\section{Metodologi Penyelesaian dengan QM}

Selain menggunakan Matlab, penelitian ini juga mencoba mencoba metode normalized goal programming dengan menggunakan perangkat lunak QM. Namun harus ada penyesuaian pada model karena QM tidak dapat menerima adanya batasan pertidaksamaan linear yang memiliki variabel deviasi, sehingga bentuk model menjadi seperti berikut ini.

$\max \lambda$

Dibatasi dengan

$$
\begin{aligned}
& f_{k}+d_{k}^{-}-d_{k}^{+}=f_{k}^{*}-\left(\lambda\left(f_{k}^{*}-f_{k}^{+}\right)-\left(f_{k}^{*}-f_{k}^{+}\right)\right) \\
& d_{k}^{+} d_{k}^{-}=0 ; k=1,2,3 \\
& d_{k}^{+}, d_{k}^{-} \geq 0 ; k=1,2,3
\end{aligned}
$$

(4), (5), dan (6)

Batasan (9b) adalah penggabungan antara batasan (8b) dan (8c) pada model normalized goal programming. Hal ini dimungkinkan karena QM hanya akan mencoba mencari nilai mendekati hasil terbaik $\left(\boldsymbol{f}_{\boldsymbol{k}}^{+}\right)$dari masing-masing fungsi tujuan awal (goal) tanpa harus melihat batasan dari target yang ingin dicapai sebelumnya $\left(\boldsymbol{f}_{\boldsymbol{k}}^{*}\right)$.

\section{HASIL DAN PEMBAHASAN}

\section{A. Validasi}

Validasi dilakukan dengan mencoba program penelitian menggunakan studi kasus lain yang sudah memiliki hasil valid. Studi kasus yang dicoba adalah studi kasus yang diteliti oleh O. Jadidi, et al (2014) mengenai pemilihan supplier [11]. Di penelitiannya, O. Jadidi menggunakan perangkat lunak GAMS Solver.

Apabila hasil yang dikeluarkan sama atau berada di tingkat kesalahan (error) yang diperbolehkan, maka dapat dikatakan model dan program sudah valid.

Berikut adalah data numerik dari studi kasus penelitian O.Jadidi, et al. (2014) :

Tabel 1 : Data numerik studi kasus untuk validasi

\begin{tabular}{|c|c|c|c|c|}
\hline Supplier & $\begin{array}{c}\text { Price } \\
(\mathbf{\$})\end{array}$ & $\begin{array}{c}\text { Defect rate } \\
(\boldsymbol{\%})\end{array}$ & $\begin{array}{c}\text { Late } \\
\text { delivery (\%) }\end{array}$ & $\begin{array}{c}\text { Capacity } \\
(\boldsymbol{k g})\end{array}$ \\
\hline S1 & 6.5 & 0.10 & 0.45 & 2500 \\
\hline S2 & 5.5 & 0.30 & 0.40 & 2500 \\
\hline S3 & 6 & 0.20 & 0.60 & 2500 \\
\hline
\end{tabular}

Studi kasus ini memiliki tujuan :

- Meminimalkan biaya pengadaan produk

$\left(f_{1}\right)$

- Meminimalkan produk cacat

$\left(f_{2}\right)$

- Meminimalkan keterlambatan produk datang $\left(f_{3}\right)$

Dan asumsikan :
- Target yang ingin dicapai untuk masing-masing fungsi tujuan $\left(f_{k}^{*}\right)$

$f_{1}^{*}=29500 ; f_{2}^{*}=9 ; f_{3}^{*}=22$

- Hasil terbaik masing-masing fungsi tujuan $\left(f_{k}^{+}\right)$

$f_{1}^{+}=28750 ; f_{2}^{+}=7.5 ; f_{3}^{+}=21.25$

Hasil validasinya ditunjukkan pada perbandingan Tabel 2 berikut ini :

Tabel 2 : Perbandingan hasil validasi

\begin{tabular}{|c|c|c|c|}
\hline & Matlab & QM & GAMS \\
\hline$f_{1}$ & 28753 & 30000 & 30000 \\
\hline$f_{2}$ & 11.472 & 10.00 & 10.00 \\
\hline$f_{3}$ & 23.3125 & 21.25 & 21.25 \\
\hline$x_{1}$ & 861 & 2500 & 2500 \\
\hline$x_{2}$ & 2479 & 2500 & 2500 \\
\hline$x_{3}$ & 1587 & 0 & 0 \\
\hline$R_{1}^{-}$ & 0.996 & -0.67 & -0.67 \\
\hline$R_{2}^{-}$ & -1.648 & -0.67 & -0.67 \\
\hline$R_{3}^{-}$ & -1.75 & 1 & 1 \\
\hline
\end{tabular}

Hasil akhir yang dikeluarkan Matlab hanya memenuhi permintaan sebanyak 4.927 unit, tidak memenuhi permintaan pelanggan sebesar 5000 unit.

Namun, jika melihat tabel perbandingan di atas, kita dapat mencari nilai Error Variance (E2) untuk mengetahui tingkat kevalidan dari hasil percobaan program Matlab. Model dikatakan valid apabila nilai E2 $\leq 30 \%$. Berikut adalah rumus menghitung nilai E2.

$$
E 2=\frac{\mid \text { Standart Deviasi Simulasi }- \text { Standart Deviasi Data } \mid}{\text { Standart Deviasi Data }}
$$

Hasil yang dihitung standart deviasinya adalah hasil goal $\left(f_{1}, f_{2}\right.$, dan $\left.f_{3}\right)$. Setelah diketahui nilai standart deviasi masing-masing, maka selanjutnya menghitung nilai E2 dengan menggunakan rumus di atas. Maka ditemukan bahwa nilai Error Variance sebesar 4,16\%, artinya model dan program yang dibuat telah valid karena nilai E2 kurang dari $30 \%$ namun program Matlab memang tidak dapat menemukan solusi yang sesuai dengan batasan yang diberikan studi kasus.

Sedangkan hasil QM menunjukkan hasil yang sama dengan yang dihasilkan O.Jadidi, et al. (2014) dengan bantuan GAMS Solver. Dengan begitu, dapat disimpulkan bahwa model normalized goal programming yang dikerjakan dengan bantuan perangkat lunak QM telah valid.

\section{B. Analisa Hasil Matlab}

Berikut adalah hasil yang dikeluarkan oleh program Matlab.

Tabel 3 : Hasil yang diperoleh dari program Matlab

\begin{tabular}{|c|c|}
\hline $\begin{array}{c}\text { Variabel Keputusan dan } \\
\text { Deviasi }\end{array}$ & Hasil \\
\hline DA1 & 0.00079999 \\
\hline DA2 & 0.00079995 \\
\hline DA3 & 0.00079997 \\
\hline
\end{tabular}




\begin{tabular}{|c|c|}
\hline y4 (supplier 1$)$ & $117.5267 \sim 118$ \\
\hline y5 (supplier 2) & $203.0826 \sim 203$ \\
\hline y6 (supplier 3) & $2.46 \mathrm{e}-011 \sim 0$ \\
\hline y7 (supplier 4) & $97.369 \sim 97$ \\
\hline y8 (supplier 5) & 175 \\
\hline y9 (supplier 6) & $6.43 \mathrm{e}-011 \sim 0$ \\
\hline
\end{tabular}

Nilai DA1, DA2, dan DA3 pada Tabel 2 merupakan variabel deviasi yang ada pada tiap batasan fungsi tujuan. Semenjak model diubah menjadi normalized goal programming, fungsi tujuan berubah menjadi memaksimalkan nilai lamda $(\lambda)$. DA adalah deviasi atas $\left(d_{k}^{+}\right)$. Untuk memudahkan dalam menganalisa hasil, dapat dilihat pada Tabel 4 di bawah ini :

Tabel 4 : Hasil yang diperoleh dari program Matlab

\begin{tabular}{|c|c|c|c|c|c|}
\hline & Matlab & & Matlab & & Matlab \\
\hline $\boldsymbol{f}_{\mathbf{1}}(\mathbf{x 1 0 0 0})$ & 5787.95 & supplier 2 & 203 & supplier 6 & 0 \\
\hline $\boldsymbol{f}_{\mathbf{2}}$ & 20.09 & supplier 3 & 0 & $\boldsymbol{R}_{\mathbf{1}}^{-}$ & 1.034 \\
\hline $\boldsymbol{f}_{\mathbf{3}}$ & 42.2 & supplier 4 & 97 & $\boldsymbol{R}_{\mathbf{2}}^{-}$ & 0.4955 \\
\hline supplier 1 & 118 & supplier 5 & 175 & $\boldsymbol{R}_{\mathbf{3}}^{-}$ & 0.593 \\
\hline
\end{tabular}

Hasil akhir yang dikeluarkan Matlab hanya memenuhi permintaan sebanyak $593 \mathrm{~kg}$, tidak memenuhi permintaan Giant sebesar $600 \mathrm{~kg}$. Namun hal ini masih dapat diperbolehkan karena masih berada pada tingkat error yang sangat kecil $(1,16 \%)$.

Jika kita melihat dari Goal 1, Goal 2, dan Goal 3, semuanya sudah memenuhi target yang diinginkan $\left(f_{k}^{*}\right)$ bahkan jauh lebih baik.

Untuk tingkat konsistensinya $\left(R_{k}^{-}\right)$, semua goal tidak memiliki tingkat konsistensi yang sama namun semua goal mendapatkan nilai $R_{k}^{-} \geq 0$. Hal ini berarti semua hasil akhir $\left(f_{k}\right)$ memenuhi target yang diinginkan $\left(f_{k}^{*}\right)$.

Dalam memenuhi permintaan buah mangga, Giant harus memesan $118 \mathrm{~kg}$ buah ke supplier 1, $203 \mathrm{~kg}$ buah ke supplier 2, $97 \mathrm{~kg}$ ke supplier 4, dan $175 \mathrm{~kg}$ ke supplier 5. Dengan begitu, biaya pesanan buah mangga akan menjadi Rp 5.787 .950 , dengan $20 \mathrm{~kg}$ buah dari $593 \mathrm{~kg}$ adalah buah cacat dan $42 \mathrm{~kg}$ buah datang terlambat.

\section{Analisa Hasil QM}

Berikut adalah hasil yang dikeluarkan oleh program QM.

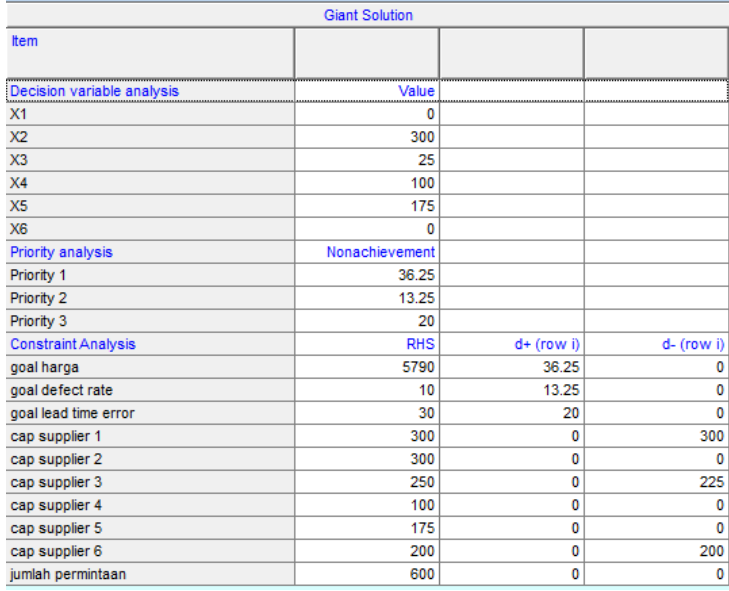

Gambar 2 : Hasil yang diperoleh dari QM
Untuk memudahkan dalam menganalisa hasil, dapat dilihat pada Tabel 5 di bawah ini :

Tabel 5 : Hasil yang diperoleh dari QM

\begin{tabular}{|c|c|c|c|c|c|}
\hline & QM & & QM & & QM \\
\hline $\boldsymbol{f}_{\mathbf{1}}(\mathbf{x 1 0 0 0})$ & 5826.25 & $\boldsymbol{x}_{\mathbf{2}}$ & 300 & $\boldsymbol{x}_{\mathbf{6}}$ & 0 \\
\hline $\boldsymbol{f}_{\mathbf{2}}$ & 23.25 & $\boldsymbol{x}_{\mathbf{3}}$ & 25 & $\boldsymbol{R}_{\mathbf{1}}^{-}$ & 0.39583 \\
\hline $\boldsymbol{f}_{\mathbf{3}}$ & 50 & $\boldsymbol{x}_{\mathbf{4}}$ & 100 & $\boldsymbol{R}_{\mathbf{2}}^{-}$ & 0.3375 \\
\hline $\boldsymbol{x}_{\mathbf{1}}$ & 0 & $\boldsymbol{x}_{\mathbf{5}}$ & 175 & $\boldsymbol{R}_{\mathbf{3}}^{-}$ & 0.33333 \\
\hline
\end{tabular}

Hasil akhir yang dikeluarkan QM memenuhi permintaan sebanyak $600 \mathrm{~kg}$ buah Giant. Jika kita melihat dari Goal 1, Goal 2, dan Goal 3, semuanya sudah memenuhi target yang diinginkan $\left(f_{k}^{*}\right)$ bahkan jauh lebih baik.

Untuk tingkat konsistensinya $\left(R_{k}^{-}\right)$, semua goal hampir memiliki tingkat konsistensi yang sama dan mendapatkan nilai $R_{k}^{-} \geq 0$. Hal ini berarti semua hasil akhir $\left(f_{k}\right)$ memenuhi target yang diinginkan $\left(f_{k}^{*}\right)$.

Dalam memenuhi permintaan buah mangga sebesar 600 $\mathrm{kg}$, Giant harus memesan $300 \mathrm{~kg}$ buah ke supplier $2,25 \mathrm{~kg}$ buah ke supplier 3, $100 \mathrm{~kg}$ ke supplier 4, dan $175 \mathrm{~kg} \mathrm{ke}$ supplier 5 sehingga dapat menekan biaya pengadaan produk buah sekecil-kecilnya. Dengan begitu, biaya pesanan buah mangga akan menjadi Rp 5.826.250, dengan 23,25 kg adalah buah cacat dan $50 \mathrm{~kg}$ buah datang terlambat.

\section{Diskusi Hasil}

Setelah melihat analisa dari masing-masing hasil dengan menggunakan program Matlab dan perangkat lunak QM, di bawah ini adalah tabel perbandingannya.

Tabel 6 : Perbandingan antara hasil Matlab dan QM

\begin{tabular}{|c|c|c|}
\hline & Matlab & QM \\
\hline $\boldsymbol{f}_{\mathbf{1}}(\mathbf{x 1 0 0 0 )}$ & 5787.95 & 5826.25 \\
\hline $\boldsymbol{f}_{\mathbf{2}}$ & 20.09 & 23.25 \\
\hline $\boldsymbol{f}_{\mathbf{3}}$ & 42.2 & 50 \\
\hline supplier 1 & 118 & 0 \\
\hline supplier 2 & 203 & 300 \\
\hline supplier 3 & 0 & 25 \\
\hline supplier 4 & 97 & 100 \\
\hline supplier 5 & 175 & 175 \\
\hline supplier 6 & 0 & 0 \\
\hline $\boldsymbol{R}_{\mathbf{1}}^{-}$ & 1.034 & 0.395833 \\
\hline $\boldsymbol{R}_{\mathbf{2}}^{-}$ & 0.4955 & 0.3375 \\
\hline $\boldsymbol{R}_{\mathbf{3}}^{-}$ & 0.593 & 0.333333 \\
\hline
\end{tabular}

Jika Giant memperbolehkan untuk tidak memenuhi seluruh permintaannya sebanyak $600 \mathrm{~kg}$, maka solusi yang dihasilkan Matlab adalah yang terbaik. Hal ini dikarenakan perbedaan pesanan dan permintaan hanya sebesar $1,16 \%$ atau $7 \mathrm{~kg}$ saja, biaya pemesanan paling rendah dibandingkan solusi alternatif lain, tingkat produk buah cacat dan keterlambatan pengiriman 
yang juga jauh lebih rendah dari target yang diinginkan pihak Giant. Untuk tingkat konsistensinya $\left(R_{k}^{-}\right)$, solusi Matlab tidak memiliki tingkat konsistensi yang sama di antara semua goal namun semua $R_{k}^{-}$memiliki hasil lebih dari 0 . Hal ini menunjukkan bahwa solusi yang dihasilkan Matlab lebih baik dari target yang diinginkan Giant.

Jika Giant mengutamakan pemesanan buah mangga harus sesuai dengan jumlah permintaan, maka solusi yang dihasilkan QM pada Skenario 1 adalah yang terbaik. Hal ini karena semua goal $\left(f_{k}\right)$ memiliki nilai yang lebih baik dari target yang diinginkan Giant $\left(f_{k}^{*}\right)$. Untuk tingkat konsistensinya $\left(R_{k}^{-}\right)$, solusi Skenario 1 pada QM hampir memiliki tingkat konsistensi yang sama di antara semua goal dan semua $R_{k}^{-}$ memiliki hasil lebih dari 0. Hal ini menunjukkan bahwa solusi yang dihasilkan Skenario 1 pada QM lebih baik dari target yang diinginkan Giant.

Namun, kedua model baik yang diimplementasi di program Matlab maupun QM dapat digunakan dalam mencoba menyelesaikan jenis permasalahan lainnya karena kedua hasil yang diperoleh menunjukkan hasil yang valid.

\section{KESIMPULAN/RINGKASAN}

Berdasarkan proses-proses yang telah dilakukan dalam penelitian tugas akhir ini, maka ada beberapa kesimpulan yang dapat diambil, di antaranya adalah :

1. Metode normalized goal programming mampu menjadi metode penyelesaian untuk kasus multi tujuan, yang mana dalam tugas akhir ini terkait pengoptimalan dalam proses pengadaan produk buah mangga Giant Ekstra Diponegoro Surabaya.

2. Kedua model baik yang diimplementasi di program Matlab maupun QM dapat digunakan dalam mencoba menyelesaikan jenis permasalahan lainnya

3. Proses validasi model dilakukan dengan mencoba program penelitian menggunakan studi kasus lain yang sudah memiliki hasil valid. Setelah hasilnya dibandingkan, hasil program Matlab menunjukkan nilai E2 (Error Variance) sebesar 4,16\%. Hal tersebut menunjukkan bahwa model sudah valid karena nilai E2 kurang dari 30\%. Sedangkan hasil model yang dikerjakan di QM menunjukkan hasil yang sama dengan hasil studi kasus lain.

4. Solusi yang diperoleh dari program Matlab tidak dapat memenuhi seluruh permintaan Giant namun hal tersebut masih diperbolehkan karena tingkat error variance-nya hanya sebesar $1,16 \%$.

5. Solusi yang diperoleh dengan menggunakan QM menujukkan hasil yang baik karena memenuhi bahkan lebih baik dari target yang ingin dicapai Giant.

6. Tingkat konsistensi $\left(R_{k}^{-}\right)$untuk solusi pertama, solusi dari program Matlab, tidak memiliki tingkat konsistensi yang sama di antara semua goal namun semua $R_{k}^{-}$ memiliki hasil lebih dari 0. Hal ini menunjukkan bahwa solusi yang dihasilkan Matlab lebih baik dari target yang diinginkan Giant.
7. Tingkat konsistensi $\left(R_{k}^{-}\right)$untuk solusi kedua, solusi Skenario 1 pada QM hampir memiliki tingkat konsistensi yang sama di antara semua goal dan semua $R_{k}^{-}$memiliki hasil lebih dari 0 . Hal ini menunjukkan bahwa solusi yang dihasilkan Skenario 1 pada QM lebih baik dari target yang diinginkan Giant

Untuk pengembangan yang lebih baik lagi, dapat ditambahkan kriteria-kriteria kualitatif (intangible) di dalam model permasalahan multitujuan. Metode AHP atau ANP dapat dikombinasikan dengan model matematis seperti normalized goal programming ini sehingga dapat menghasilkan solusi yang jauh lebih baik lagi.

\section{UCAPAN TERIMA KASIH}

Terima kasih kepada manajemen Giant Ekstra Diponegoro Surabaya yang telah memberikan kesempatan untuk mengumpulkan data dan inforamsi terkait keperluan penelitian ini.

\section{DAFTAR PUSTAKA}

[1] E. Wirdianto and E. Unbersa, "Aplikasi Metode Analytical Hierarchy Process dalam Menentukan Kriteria Penilaian Supplier," 2008.

[2] G. Dickson, "An Analysis of Vendor Selection: Systems and Decisions," Journal of Purchasing, pp. 5-17, 1966.

[3] G. Wang, S. Hang and J. Dismukes, "Product-driven supply chain selection using integrated multi-criteria decision making methodology," International Journal of Production Economics, vol. 91, pp. 1-15, 2004.

[4] S. Ghodsypour and C. O'Brien, "A decision support system for supplier selection using an integrated analytical hierarchy process and linear programming," International Journal of Production Economics, Vols. 56-57, pp. 199-212, 1998.

[5] O. Jadidi, S. Cavalieri and S. Zolfaghari, "An imporved multi-choice goal programming approach for supplier selection problems," Applied Mathematical Modelling, 2014.

[6] R. Caballero, T. Gomez and F. Ruiz, "Goal programming: realistic targets for the near future," Journal Multi-Criteria Decision Analytics, pp. 79-110, 2009.

[7] M. Kumar, P. Vart and R. Shankar, "A fuzzy goal prgoramming approach for supplier selection problem in a supply chain," Computers and Industrial Engineering, pp. 69-85, 2004.

[8] A. Amid, S. Ghodsypour and C. O'Brien, "A weighted max-min model for fuzzy multi-objective supplier selection in a supply chain," International Journal of Production Economics, pp. 139-145, 2011.

[9] O. Ustun and E.A.Demirtas, "Multi-period lot-sizing with supplier selection using achievement scalarizing functions," Comput. Ind. Eng, 2008.

[10] S. Nazari-Shirkouhi, H. Shakouri, B. Javadi and A. Keramati, "Supplier selection and order allocation problem using a two-phase fuzzy multiobjective linear programming," Applied Mathematics Modelling, 2013.

[11] O. Jadidi, S. Zolfaghari and S. Cavalieri, "A new normalized goal programming model for multi-objective problems: A case of supplier selection and order allocation," Int. J. Production Economics, 2014.

[12] D. Simchi-levi, Designing and managing the suppy chain, Mac Grawhill.

[13] S. Chopra and P. Meindl, Supply Chain Management: Strategy, Planning, and Operating, Prentice Hall.

[14] E. A. Demirtas and O. Ustun, "An Integrated Multi-objective Decision Making Process for Supplier," 2005.

[15] H. A. Simon, "Making management decisions: the role of intuition an emotion," Academy of Management Executive, vol. 1, no. 1, pp. 57-64, 1987. 